\title{
Acanthopanax senticosus polysaccharide suppressing proliferation and metastasis of the human non-small cell lung cancer NCI-H520 cells is associated with $\mathrm{Wnt} / \beta$-catenin signaling
}

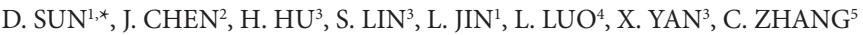 \\ ${ }^{1}$ Institute of Life Sciences, Wenzhou University, Wenzhou, China; ${ }^{2}$ Sichuan Provincial Medical Center of Mental Health \& Sichuan Provincial \\ People's Hospital, Sichuan, China; ${ }^{3}$ School of Pharmaceutical Sciences, Wenzhou Medical University, Wenzhou, China; ${ }^{4}$ Bioengineering College, \\ Chongqing University, Chongqing, China; ${ }^{5}$ The Third Affiliated Hospital of Wenzhou Medical University, Wenzhou, China
}

*Correspondence: sunda_dsd@163.com

Received September 13, 2018 / Accepted January 15, 2019

\begin{abstract}
Lung cancer (LC) has the highest mortality of all tumors. Non-small cell lung cancer (NSCLC) accounts for about $80 \%$ of all LC. Acanthopanax senticosus polysaccharide (ASPS) is extracted from the root of Acanthopanax senticosus (AS). Herein, we examined the effect and molecular mechanism of ASPS on NSCLC. The proliferation, invasion and migration of NCI-H520 cells were detected by cell counting kit-8 (CCK-8), transwell assay and wound healing assay, respectively. The epithelial-mesenchymal transition (EMT) and Wnt/ $\beta$-catenin pathway-related factors were evaluated using quantitative real-time PCR (qRT-PCR) and western blot assay. Our results showed that ASPS significantly decreased the proliferation of cells at 24 and $48 \mathrm{~h}$. Moreover, ASPS markedly repressed the invasion and migration capacities of cells in a concentrationdependent manner. Besides, ASPS obviously downregulated the levels of matrix metalloproteinase-2 (MMP-2), MMP-9, fibronectin 1 (FN1), vimentin, wnt3a, phosphorylated-glycogen synthase kinase $3 \beta$ (p-GSK3 $\beta$ ) and cyclin D1, whereas E-cadherin level was upregulated. The level of GSK3 $\beta$ was not changed within the different groups. ASPS conspicuously inhibited the abilities of proliferation and metastasis in human non-small cell lung cancer cell line NCI-H520 possibly by suppressing Wnt/ $\beta$-catenin pathway mediated-EMT.
\end{abstract}

Key words: Acanthopanax senticosus polysaccharide, proliferation, metastasis, Wnt/ß-catenin pathway

Lung cancer (LC) has the highest mortality of all tumors and about 1.5 million people die of LC each year worldwide. According to the histologic characteristic, LC is divided into two types: small cell lung cancer (SCLC) and non-small cell lung cancer (NSCLC) [1]. The proportion of NSCLC patients in newly diagnosed LC patients is up to $85 \%$ per year and the 5-year survival rate is less than $15 \%$ [2]. Although chest screening, low dose CT and other early screening methods are widely used in the early detection of NSCLC, the most patients are in middle and late stage when diagnosed, thereby losing the chance of surgical cure $[3,4]$. At the present, treatment of NSCLC mainly includes chemotherapy, molecular targeted therapy and immunotherapy [4]. However, these treatments have some side effects and the patient's survival rate is still very low $[5,6]$. Hence, we need to examine the specific pathogenesis of NSCLC and find a safe and effective treatment.
It is well known that the widespread use of Chinese herbal medicine in the treatment of various tumors is a hot spot of research [7-9]. Researchers have proved that the antitumor activity of Chinese herbal medicine is mainly derived from the plant extracts, including polysaccharides, saponins, steroids, etc. [10-12]. In recent years, the extensive biological activity of plant polysaccharides has been gradually recognized [13]. The antitumor research of polysaccharide has aroused wide attention of scholars both at home and abroad $[14,15]$.

Acanthopanax senticosus (AS) belongs to Chinese herbal medicine [16]. Acanthopanax senticosus polysaccharide (ASPS) is extracted from the root of AS and is one of the main active components of AS [17]. The bioactivities of ASPS include immunomodulatory, antitumor, antioxidant, antiradiation and anti-inflammatory [18-21]. Meanwhile, it has the advantages of low toxicity, so it has a great potential in 
clinical application [22, 23]. Nevertheless, the role of ASPS in NSCLC is not yet known.

The development of tumor is the evolutionary process of multifactor, multigene and multistage gradual accumulation. Cell signal transduction pathway plays a pivotal role in its development, invasion and metastasis $[24,25]$. As we know, the $W n t / \beta$-catenin signal transduction pathway plays an important regulatory role in cell differentiation, proliferation, survival and apoptosis, as well as cell carcinogenesis, tumor invasion and other pathological processes [26]. $\mathrm{Wnt} / \beta$-catenin pathway is closely related to the tumors and the abnormal activation of the pathway is involved in the pathogenesis of a variety of human cancers, such as nasopharyngeal carcinoma, gastric cancer, liver cancer, breast cancer, prostate cancer, etc. [27-32].

At the present study, we explored the effect of ASPS on the proliferation and metastasis of human non-small cell lung cancer line NCI-H520 and further studied whether the potential mechanism was the Wnt/ $\beta$-catenin pathway involvement.

\section{Materials and methods}

Drug treatment. Acanthopanax senticosus polysaccharide (ASPS) was extracted from the cortex of Acanthopanax senticosus. The powder of Acanthopanax senticosus polysaccharide was purchased from Shaanxi Ciyuan Biotechnology Co., Ltd. The color was brown and the purity was more than $80 \%$. The powder was dissolved in serum-free Roswell Park Memorial Institute-1640 (RPMI-1640) (Biosun, Shanghai, China) and filtered through $0.22 \mu \mathrm{m}$ membrane (Shenghua; Haining, Jiaxing, China). The solution of ASPS was diluted to $10,20,40,80,160$ and $320 \mathrm{mg} / \mathrm{ml}$ in RPMI- 1640 .

Cell culture. Human non-small cell lung cancer cell line NCI-H520 was obtained from Shanghai enzyme linked Biotechnology Co., Ltd. Cells were incubated in RPMI-1640 supplemented with 10\% Fetal Bovine Serum (FBS; Lonsera, Shanghai, China) and penicilin-streptomycin solution

Table 1. Sequences of the primers.

\begin{tabular}{|c|c|c|}
\hline Primer name & Sequence (5'-3') & $\begin{array}{l}\text { Product } \\
\text { size (bp) }\end{array}$ \\
\hline MMP-2-Forward & CAGCCCTGCAAGTTTCCATT & \multirow{2}{*}{210} \\
\hline MMP-2-Reverse & GTTGCCCAGGAAAGTGAAGG & \\
\hline MMP-9-Forward & GAGACTCTACACCCAGGACG & \multirow{2}{*}{238} \\
\hline MMP-9-Reverse & GAAAGTGAAGGGGAAGACGC & \\
\hline FN1-Forward & TGGCACTGATGAAGAACCCT & \multirow{2}{*}{224} \\
\hline FN1-Reverse & GGGAAACTGTGTAGGGGTCA & \\
\hline Vimentin-Forward & AATAAGATCCTGCTGGCCGA & \multirow{2}{*}{225} \\
\hline Vimentin-Reverse & GGTGTTTTCGGCTTCCTCTC & \\
\hline E-cadherin-Forward & ACGCATTGCCACATACACTC & \multirow{2}{*}{217} \\
\hline E-cadherin-Reverse & GGTGTTCACATCATCGTC & \\
\hline$\beta$-actin-Forward & GGGAAATCGTGCGTGACATT & \multirow{2}{*}{219} \\
\hline$\beta$-actin-Reverse & AGGTAGTTTCGTGGATGCCA & \\
\hline
\end{tabular}

(Leagene, Beijing, China) in $37^{\circ} \mathrm{C}$ incubator (S-G80A-II; Sheyanyiqi, Shanghai, China) with $95 \%$ relative humidity and $5 \% \mathrm{CO}_{2}$.

Cell Counting Kit-8 (CCK-8) assay. CCK-8 (Yeasen, Shanghai, China) was used to assess the cell proliferation as manufacturer's instructions recommend. Firstly, cells were inoculated into 96 -well plates at the density of $1.5 \times 10^{3}$ cells/ well and cultured in incubator for $24 \mathrm{~h}$. Next day, cells were treated with PBS and different concentration of ASPS $(0,10$, $20,40,80,160$ and $320 \mathrm{mg} / \mathrm{ml}$ ) for 12,24 and $48 \mathrm{~h}$, respectively. Then, CCK- 8 solution was dripped into each well and the plate was transferred into the incubator for $4 \mathrm{~h}$. Finally, OD value at $450 \mathrm{~nm}$ was detected by HBS-1096B microplate reader (Detie, Nanjing, China).

Transwell assay. Transwell assay was carried out to evaluate cell invasion according to the manufacturer's instructions. Briefly, cells were inoculated into 6-well plates at the density of $2 \times 10^{4}$ cells/well and cultured in incubator for $24 \mathrm{~h}$. Next day, cells were treated with PBS (control) and different concentration of ASPS: 40 (ASPS1), 80 (ASPS2) and 160 (ASPS3) $\mathrm{mg} / \mathrm{ml}$ for $48 \mathrm{~h}$, respectively. BD matrigel (Solarbio, Shanghai, China) was filled in the upper chamber of transwell at $37^{\circ} \mathrm{C}$ for $30 \mathrm{~min}$. Then, transwell was placed into the culture plate. RPMI-1640 was added into the upper chamber of transwell for $25 \mathrm{~min}$ and sucked away. 10\% FBS was dropped into the lower chamber of the transwell. Subsequently, cell suspension was cultured in the upper chamber of transwell for $24 \mathrm{~h}$. Cells were stained with $0.1 \%$ crystal violet (Zhongxin chemtech; Tianjin, China) for $20 \mathrm{~min}$ and washed with PBS for 3 times. Finally, cells were observed and photographed using inverted microscope (DYS-339; Dianying, Shanghai, China).

Wound healing assay. Wound healing test was performed to analyze cell migration following a standardized method. Firstly, cells were inoculated into 6-well plates at the density of $2 \times 10^{4}$ cells/well and cultured in incubator for $24 \mathrm{~h}$. Next day, cells were scratched about $500 \mu \mathrm{m}$ width by $1 \mathrm{~mL}$ pipette tip and washed with RPMI-1640 for 2 times. Then, cells were treated with PBS (control) and different concentration of ASPS at 40 (ASPS1), 80 (ASPS2) and 160 (ASPS3) $\mathrm{mg} / \mathrm{ml}$ for 0,24 and 48 h, respectively. Finally, cells were observed and photographed using inverted microscope.

Quantitative real-time PCR (qRT-PCR) assay. Total RNA of was collected by TRIeasy ${ }^{\mathrm{mi}}$ Total RNA Extraction Reagent (Yeasen, Shanghai, China). cDNA was synthesized by ABScript II cDNA first strand synthesis kit (ABclonal, Beijing, China). The reaction reagents were as follows: $1 \mu \mathrm{g}$ RNA, $2 \mu \mathrm{ld}(\mathrm{T})_{23} \mathrm{VN}, 10 \mu \mathrm{l}$ ABScript II reaction mix, $2 \mu \mathrm{l}$ ABScript II enzyme mix, $1 \mu \mathrm{ldNTP}$, nuclease-free $\mathrm{H}_{2} \mathrm{O}$ to a total volume of $20 \mu \mathrm{l}$. Reaction conditions were $80^{\circ} \mathrm{C}$ for 5 min. Then, cDNA was amplified by SYBR Premix Taq ${ }^{\mathrm{mm}}$ II kit (Takara, Beijing, China). The reaction reagents were as follows: $25 \mu \mathrm{l}$ SYBR Green Mix, $4 \mu \mathrm{l}$ cDNA, $1 \mu \mathrm{l}$ forward/ reverse primer, nuclease-free $\mathrm{H}_{2} \mathrm{O}$ to a total volume of $50 \mu$ l. Reaction conditions were as followed: predegeneration: $95^{\circ} \mathrm{C}$ 
for $5 \mathrm{~min}$, (denaturation: $95^{\circ} \mathrm{C}$ for $15 \mathrm{~s}$; annealing: $62^{\circ} \mathrm{C}$ for $35 \mathrm{~s}$ ) for 40 cycles, extending: $75^{\circ} \mathrm{C}$ for $30 \mathrm{~s}$. The primer sequence was listed in the Table 1 . $\beta$-actin was regarded as internal control. The formula $2^{-\Delta \Delta \mathrm{CT}}$ was used to compare the quantification.

Western blot assay. Total protein was lysed with high RIPA lysis buffer (Leagene, Beijing, China). Protein was separated using sodium dodecyl sulfate-polyacrylamide gel electrophoresis (SDS-PAGE) and bound to polyvinylidene difluoride (PVDF) membrane (Thermo Fisher Scientific, Shanghai, China). Then, membrane was sealed by $5 \%$ skim milk at room temperature for $1.5 \mathrm{~h}$ and incubated with anti-matrix metalloproteinase-2 (MMP-2) (R\&D, IC903G100UG, 1:1000), anti-MMP-9 (Abcam, EP1254, 1:500), antifibronectin 1 (FN1) (Abcam, ab32419, 1:800), anti-vimentin (R\&D, AF2105, 1:700), anti-E-cadherin (R\&D, MAB1838, 1:1000), anti-wnt3a (Abcam, ab28472, 1:800), anti- $\beta$-catenin (R\&D, AF1329, 1:1000), anti-phosphorylated-glycogen synthase kinase $3 \beta$ (p-GSK3 $\beta$ ) (Abcam, ab75814, 1:1000), anti-GSK3 $\beta$ (Abcam, ab32391, 1:1000), anti-cyclin D1 (R\&D,
MAB4314, 1:900) and anti- $\beta$-actin (Abcam, ab13772, 1:800) at $4{ }^{\circ} \mathrm{C}$ refrigerator overnight. Next day, membrane was incubated with the secondary antibodies (Rabbit anti-mouse IgG, CST, \#58802, 1:7000; Goat anti-rabbit IgG, Beyotime, A0423, 1:8000; Donkey anti-goat IgG, Beyotime, A0181, $1: 8000)$ at $37^{\circ} \mathrm{C}$ for $60 \mathrm{~min}$. The protein was exposed using the ECL chromogenic solution (Biodragon, Beijing, China).

Statistical analysis. All experiments were carried out at least three times. Experimental data was presented as mean \pm standard deviation (SD) using Microsoft Excel. One-way ANOVA was performed to evaluate the differences between groups. A $\mathrm{p}<0.05$ was treated as a significant difference.

\section{Results}

ASPS decreased the proliferation of NCI-H520 cells. The effect of ASPS on the proliferation of NCI-H520 cells was measured by CCK-8. The data showed that there was no obvious change in cell proliferation, when cells were administrated to ASPS at $10,20,40,80,160$ and $320 \mathrm{mg} / \mathrm{ml}$ for
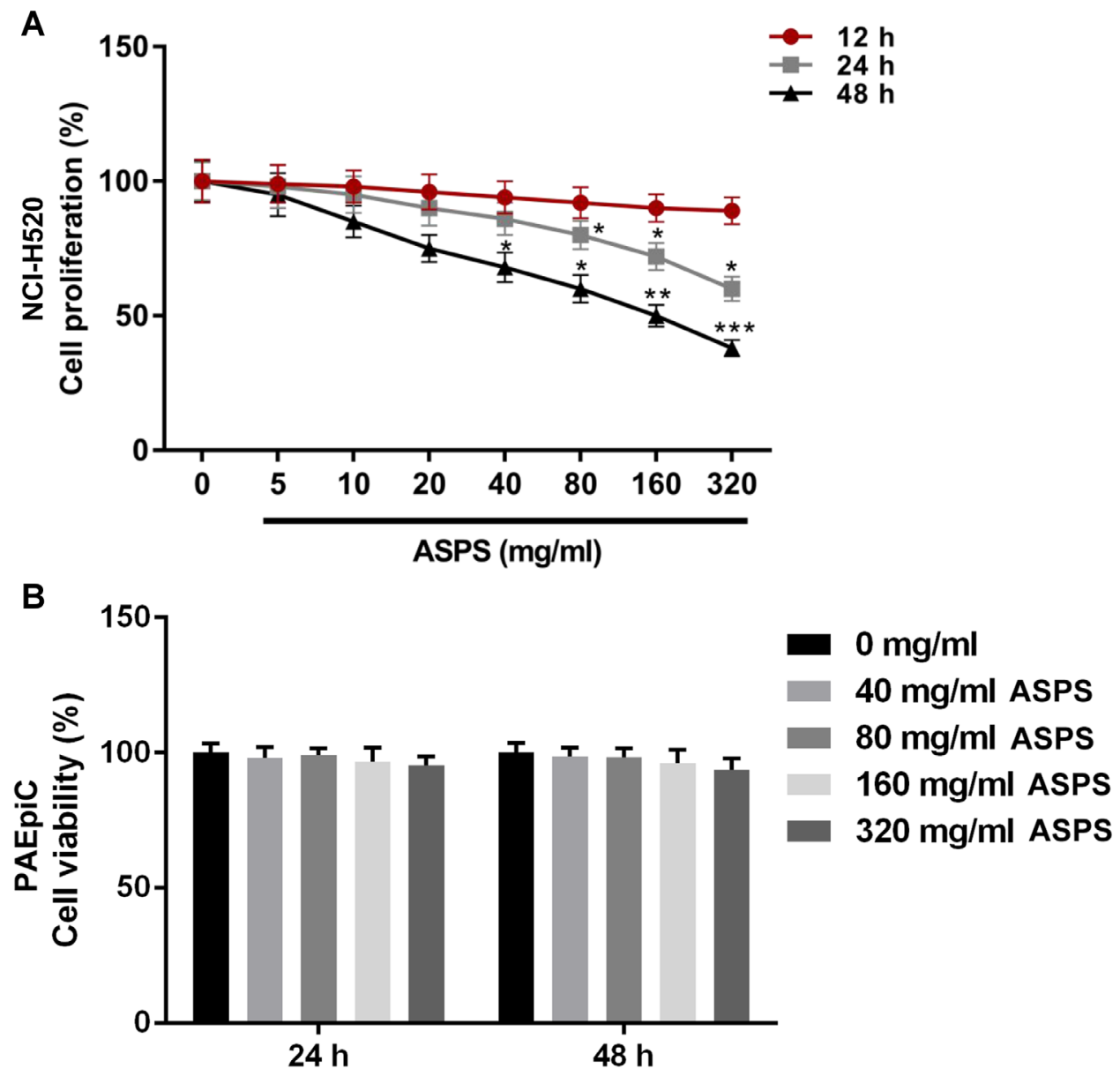

Figure 1. The effect of ASPS on cell viabilities of NCI-H520 cell and human pulmonary alveolar epithelial cell (PAEpiC). (A) NCI-H520 cells were administrated to PBS (0) and different concentrations of ASPS: 0, 10, 20, 40, 80, 160 and $320 \mathrm{mg} / \mathrm{ml}$ for 12, 24 and $48 \mathrm{~h}$, respectively. B) PAEpiC cells were administrated to PBS (0) and different concentrations of ASPS at $0,40,80,160$ and $320 \mathrm{mg} / \mathrm{ml}$ for 24 and $48 \mathrm{~h}$, respectively. CCK-8 was used to evaluate the cell proliferation. ${ }^{*} \mathrm{p}<0.05,{ }^{* *} \mathrm{p}<0.01,{ }^{* * *} \mathrm{p}<0.001$ vs. control (PBS). 
$12 \mathrm{~h}$. Besides, ASPS markedly inhibited cell proliferation for 24 and $48 \mathrm{~h}$ and $80 \mathrm{mg} / \mathrm{ml}$ ASPS significantly inhibited cell proliferation compared to control $(0 \mathrm{mg} / \mathrm{ml})$ at $24 \mathrm{~h}$. The IC50 of ASPS was $160 \mathrm{mg} / \mathrm{ml}$ at $48 \mathrm{~h}$. When the cells were treated with $320 \mathrm{mg} / \mathrm{ml}$ for $48 \mathrm{~h}$, the rate of cell proliferation was less than 50\% (Figure 1A). Moreover, study also demonstrated that $160 \mathrm{mg} / \mathrm{ml}$ ASPS treatment for 24 and $48 \mathrm{~h}$ had no significant inhibitory effect on human pulmonary alveolar epithelial cell viability (Figure 1B). Therefore, 40, 80 and $160 \mathrm{mg} / \mathrm{ml}$ ASPS treatment for $48 \mathrm{~h}$ were worth further investigating and were determined as the later experimental condition.

ASPS repressed the invasion of NCI-H520 cells. The effect of ASPS on the invasion of NCI-H520 cells was detected by transwell assay. Our results showed that the number of cell invasion was drastically reduced, when cells were administrated to ASPS. As quantitative analysis of cell invasiveness showed, the rates of cell invasion were $65 \%, 45 \%$ and $30 \%$ in ASPS1, ASPS2 and ASPS3 groups, respectively. In comparison with control group, the invasiveness of cells was decreased by 35\%, 55\% and 70\% in ASPS1, ASPS2 and ASPS3 groups, respectively (Figures 2A-B).

ASPS suppressed the migration of NCI-H520 cells. The effect of ASPS on the migration of NCI-H520 cells was analyzed by wound healing test. Our data showed that the number of cell migration was dramatically reduced, when the cells were administrated to ASPS. As quantitative analysis of cell migration showed, cell migration rates were $80 \%$, $56 \%$ and $33 \%$ in ASPS1, ASPS2 and ASPS3 groups for $24 \mathrm{~h}$, respectively. Cell migration rates were $60 \%, 50 \%$ and $25 \%$ in ASPS1, ASPS2 and ASPS3 groups for $48 \mathrm{~h}$, respectively. The rates of cell migration were lessened by $20 \%, 44 \%$ and $67 \%$ in ASPS1, ASPS2 and ASPS3 groups for $24 \mathrm{~h}$, respectively, compared with the control group. The rates of cell migration were reduced by $40 \%, 50 \%$ and $75 \%$ for $48 \mathrm{~h}$, respectively, compared to the control group (Figures $3 \mathrm{~A}-\mathrm{B}$ ).

ASPS suppressed the metastasis of NCI-H520 cells by regulating EMT-related factors. qRT-PCR and western blot assays were used to assess EMT-related factors. The qRT-PCR data revealed that the RNA levels of MMP-2, MMP-9, FN1 and vimentin were obviously declined and E-cadherin RNA level was enhanced in ASPS groups in dose-dependent manner, relative to the control group (Figure 4A). In addition, western blot data showed that the expression trend of protein was the same as that of RNA (Figure 4B).

ASPS suppressed the proliferation and metastasis of NCI-H520 cells by downregulating Wnt/ $\beta$-catenin pathway. The molecular mechanism of ASPS on the proliferation and metastasis of NCI-H520 cells was examined by western blot assay. As western blot results showed that as compared with control group, ASPS significantly downreg-
A

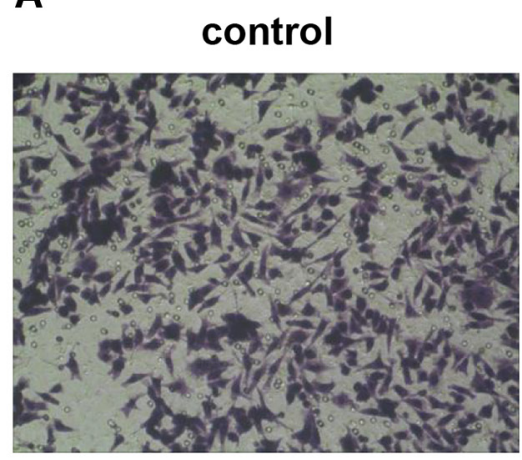

ASPS3

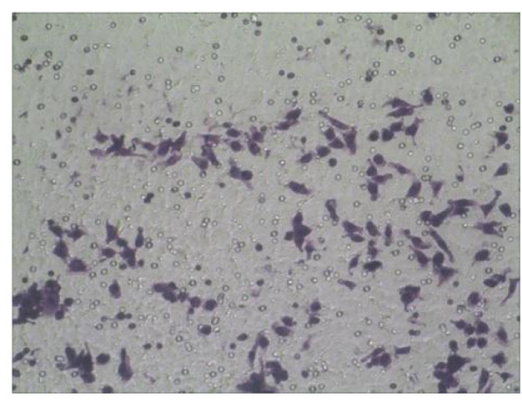

ASPS1

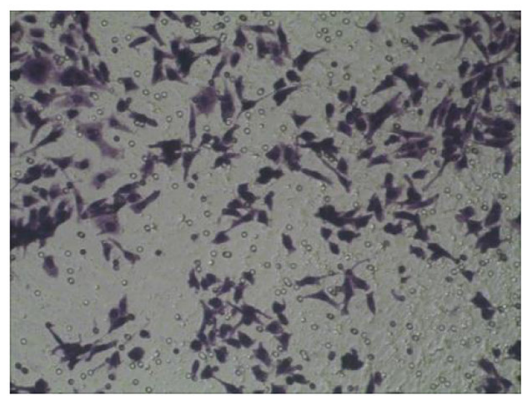

\section{ASPS2}

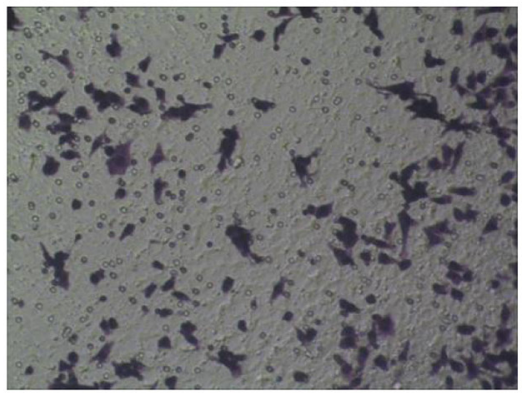

B

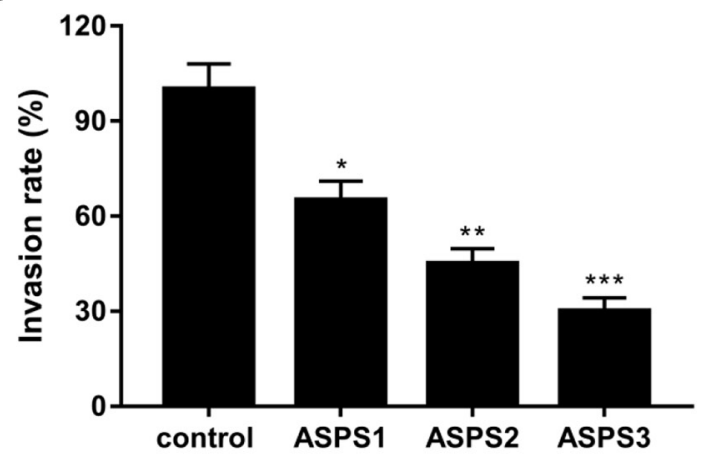

Figure 2. ASPS repressed the invasion of NCI-H520 cells. A) Cells were treated with PBS (control) and different concentrations of ASPS: 40 (ASPS1), 80 (ASPS2) and 160 (ASPS3) $\mathrm{mg} / \mathrm{ml}$ for $48 \mathrm{~h}$, respectively. Transwell assay was performed to detect cell invasion. B) Quantitative analysis of cell invasiveness was carried out with GraphPad prism 7. ${ }^{*}<0.05,{ }^{* *} \mathrm{p}<0.01,{ }^{* *} \mathrm{p}<0.001$ vs. control. 
A

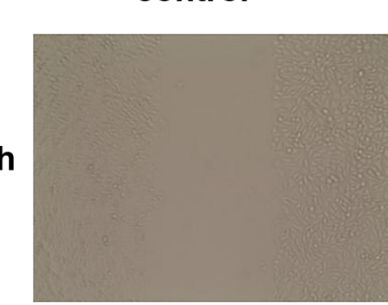

$24 \mathrm{~h}$

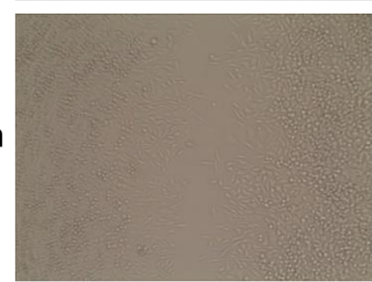

$48 \mathrm{~h}$

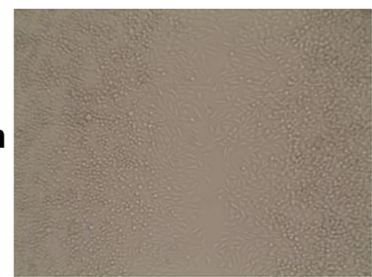

ASPS1
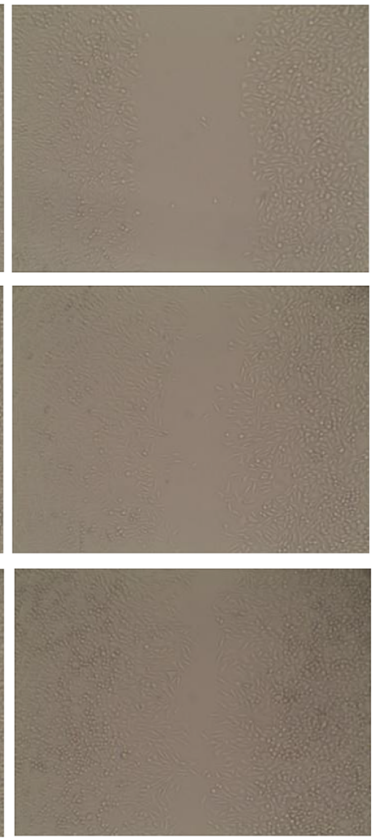

B
ASPS2
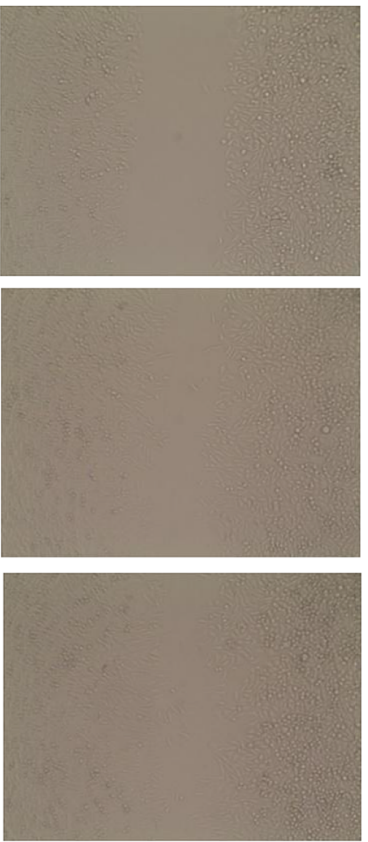

ASPS3
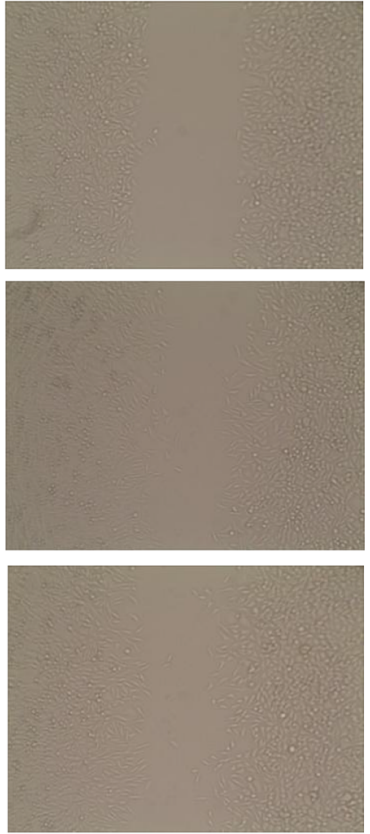

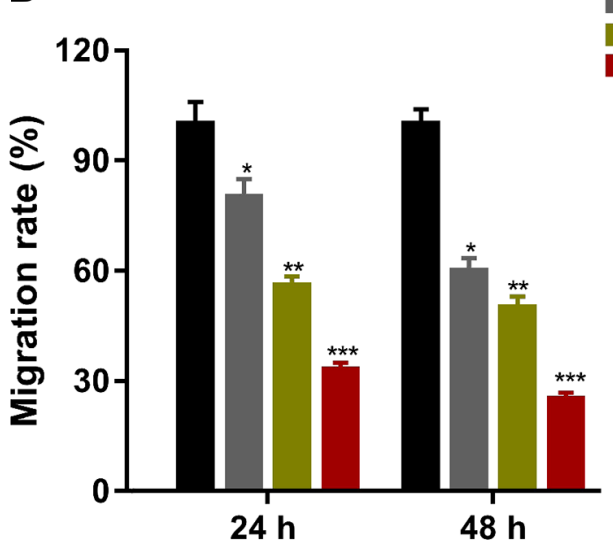

Figure 3. ASPS suppressed the migration of NCI-H520 cells. A) Cells were treated with PBS (control) and different concentrations of ASPS: 40 (ASPS1), 80 (ASPS2) and 160 (ASPS3) $\mathrm{mg} / \mathrm{ml}$ for 0, 24 and $48 \mathrm{~h}$, respectively. Wound healing assay was used to explore cell migration. B) Quantitative analysis of cell migration rate was carried out with GraphPad prism $7 .{ }^{\star} p<0.05,{ }^{* *} \mathrm{p}<0.01,{ }^{* * *} \mathrm{p}<0.001$ vs. control.

ulated the protein levels of wnt3a, $\beta$-catenin, cyclin D1 in a concentration-dependent manner. Meanwhile, the phosphorylation level of GSK3 $\beta$ was attenuated in ASPS groups in dose-dependent manner. Moreover, there was no significant change in the expression of GSK3 $\beta$ protein between different groups (Figure 5).

\section{Discussion}

For decades, accumulating evidence testifies that plant polysaccharides have obvious anticancer activity $[14,15,33]$.
Han et al. have found that Sargassum henslowianum polysaccharide can treat gastric cancer by improving the immunomodulatory function [14]. Ayeka PA et al. have confirmed that licorice polysaccharide inhibits the growth of tumor, thereby improves the health of mice [33]. Therefore, we inferred that ASPS had the effect of anti-NSCLC. As expected, ASPS distinctly repressed the proliferation of NCI-H520 cells in concentration-dependent manner at 24 and $48 \mathrm{~h}$.

Cancer metastasis is the most dangerous stage in the process of tumorigenesis and evolution and is the most important cause of cancer death, as well a key factor 
A

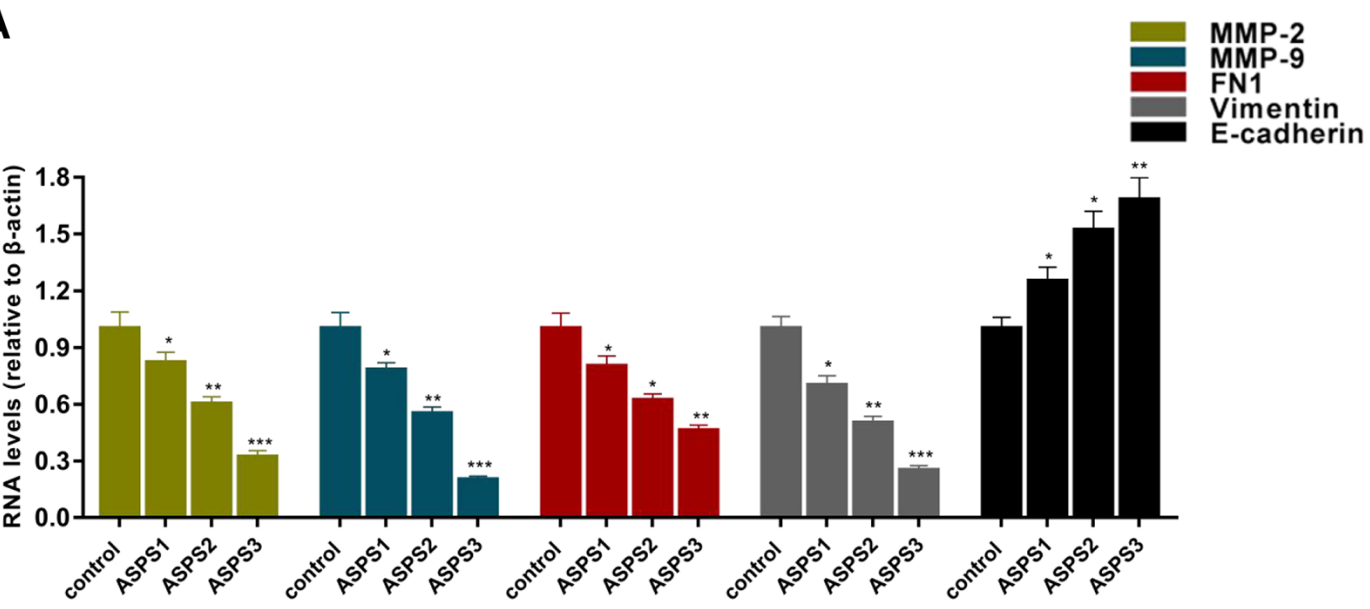

B
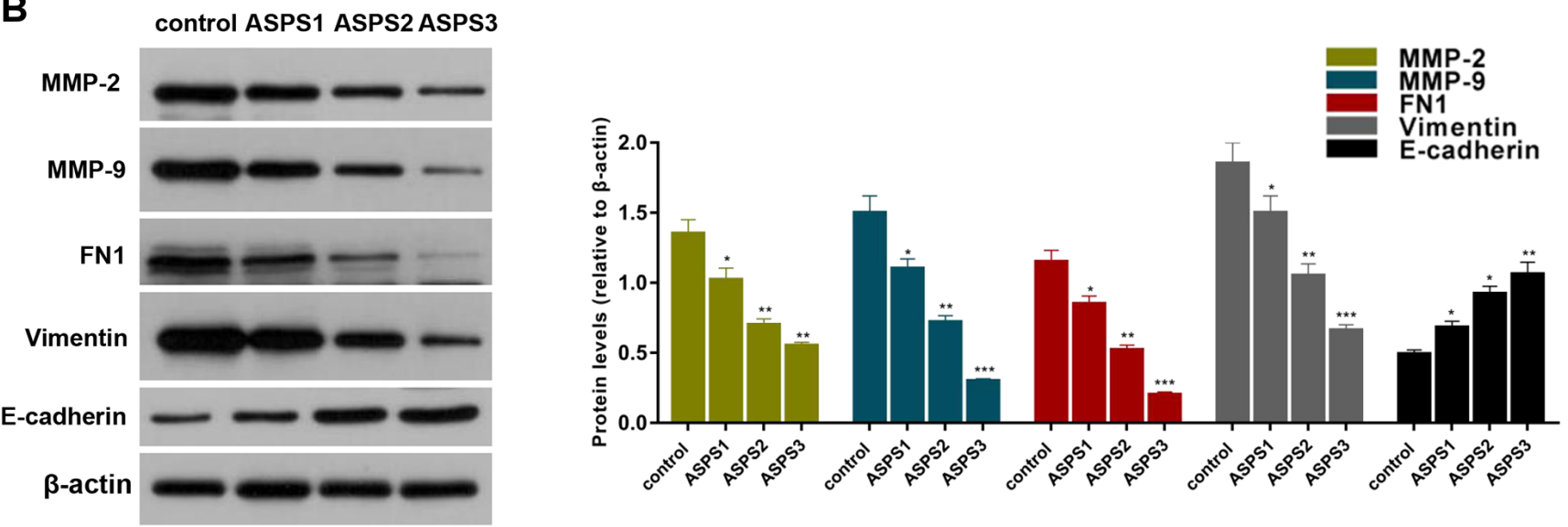

Figure 4. ASPS suppressed the metastasis of NCI-H520 cells by regulating EMT-related factors. A) RNA levels of MMP-2, MMP-9, FN1, vimentin and E-cadherin were analyzed by qRT-PCR assay. B) The protein levels of MMP-2, MMP-9, FN1, vimentin and E-cadherin were measured by western blot assay and normalized to $\beta$-actin expression. Gray value was detected and counted by quality one. ${ }^{\star} p<0.05,{ }^{\star *} p<0.01,{ }^{* * *} p<0.001$ vs. control.
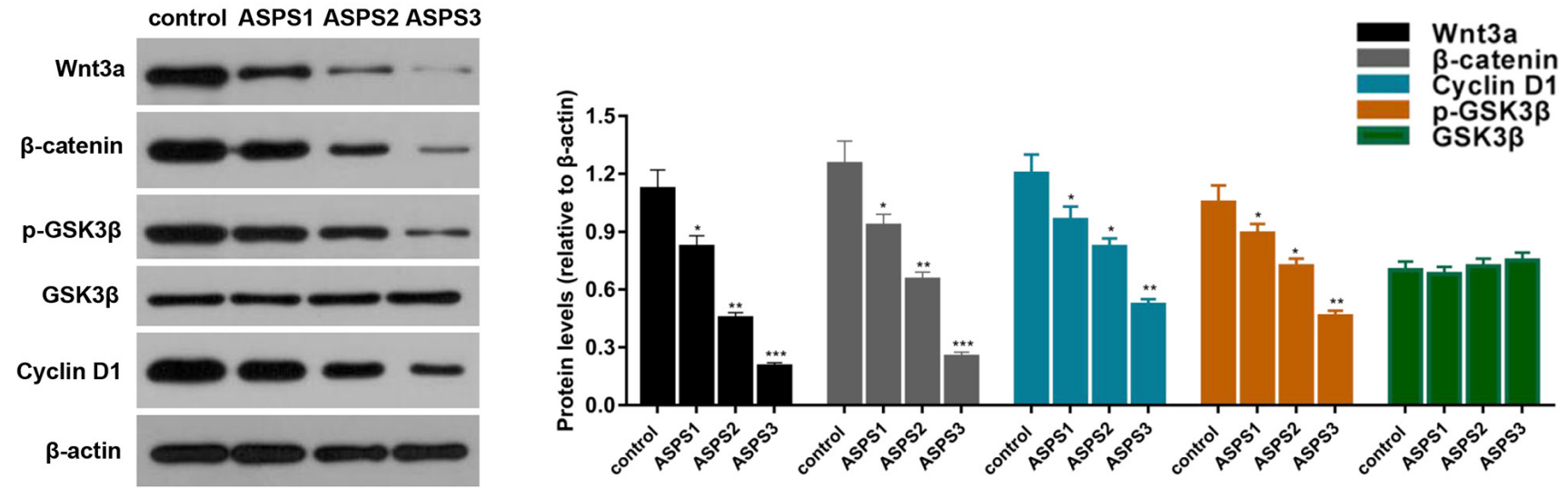

Figure 5. ASPS suppressed the proliferation and metastasis of NCI-H520 cells by downregulating Wnt/ $\beta$-catenin pathway. The protein levels of Wnt3a, $\beta$-catenin, Cyclin D1, p-GSK3 $\beta$ and GSK3 $\beta$ were evaluated by western blot assay. $\beta$-actin was regarded as internal control. ${ }^{\star} p<0.05,{ }^{* *} p<0.01$, ${ }^{* * *} \mathrm{p}<0.001$ vs. control. 
affecting the effect of tumor treatment [34]. Recent research has demonstrated that Hizikia fusiformis polysaccharide represses the invasion ability of human fibrosarcoma cells [35]. Furthermore, it has been found that Acorus calamus L. polysaccharide reduces the metastasis of lung cancer cells [36]. Similar to previous studies, our data showed that ASPS markedly reduced the invasion and migration capacities of NCI-H520 cells in a dose-dependent manner.

Metastasis of tumor cells involves the regulation of epithelial-mesenchymal transition (EMT) process-related molecules. EMT-related factors include MMPs, FN, vimentin, E-cadherin, and so on [37-39]. A study has proved that FBXO11 facilitates the capacities of proliferation and metastasis in gastric cancer cells through inducing EMT process [37]. Another research confirms that SPARC reduces the growth, invasion and migration of T-cell non-Hodgkin's lymphoma cells by inhibiting EMT process [40]. In addition, accumulating evidence substantiates that when the metastasis of the tumor cells is suppressed, the EMT process is blocked, accompanied by a decrease in the expression levels of MMP-2, MMP-9, vimentin and FN and an increase in E-cadherin expression $[38,39]$. In this study, we observed that ASPS repressed the proliferation and metastasis of NCI-H520 cells by blocking EMT process, which downregulated levels of MMP-2, MMP-9, vimentin and FN1 and upregulated E-cadherin levels.

A large number of studies have shown that genes and drugs inhibit the growth and metastasis of various cancer cells by regulating the Wnt/ $\beta$-catenin pathway $[27-29,31]$. Moreover, Wnt $/ \beta$-catenin pathway can induce EMT transformation by inhibiting GSK3 $\beta$-mediated phosphorylation and the degradation of $\beta$-catenin and further represses downstream target genes, such as cyclin D1 [31,41]. A previous report indicated that transmembrane 4 L6 family proteins silencing depressed the metastasis of NSCLC via downregulating Wnt $/ \beta$-catenin and EMT signaling [42]. As expected, our results illustrated that ASPS significantly lessened metastasis of NCI-H520 cells via $\mathrm{Wnt} / \beta$-catenin signaling pathway mediated-EMT. Though, validation experiments were also required, it was the limitation of the current study and we are planning to use antagonists or agonists to validate the possible signaling pathway.

All in all, our research testified that ASPS significantly repressed the proliferation, invasion and migration abilities of human non-small cell lung cancer NCI-H520 cells through suppressing $\mathrm{Wnt} / \beta$-catenin pathway mediated-EMT. Based on the results of this study, ASPS may be developed as a drug for the treatment of NSCLC in the future.

Acknowledgements: This work was supported by Wenzhou Science \& Technology Innovation Project in Water Pollution Control \& Manage [Grant number: W20170010]; Zhejiang Pharmaceutical Top Priority Academic Open Fund [Grant number: 201720]. The analyzed data sets generated during the study are available from the corresponding author on reasonable request.

\section{References}

[1] JEMAL A, BRAY F, CENTER MM, FERLAY J, WARD E et al. Global cancer statistics. CA Cancer J Clin 2011; 61: 69-90. https://doi.org/10.3322/caac.20107

[2] HUANG YT, HEIST RS, CHIRIEAC LR, LIN X, SKAUG V et al. Genome-wide analysis of survival in early-stage nonsmall-cell lung cancer. J Clin Oncol 2009; 27: 2660-2667. https://doi.org/10.1200/JCO.2008.18.7906

[3] CHEN Z, WANG J, BAI Y, WANG S, YIN X et al. The associations of TERT-CLPTM1L variants and TERT mRNA expression with the prognosis of early stage non-small cell lung cancer. Cancer Gene Ther 2017; 24: 20-27. https://doi. org/10.1038/cgt.2016.74

[4] RUSSO AE, PRIOLO D, ANTONELli G, LIBRA M, MCCUBREY JA et al. Bevacizumab in the treatment of NSCLC: patient selection and perspectives. Lung Cancer (Auckl) 2017; 8: 259-269. https://doi.org/10.2147/LCTT.S110306

[5] BEGUM S, HAYASHI M, OGAWA T, JABBOURE FJ, BRAIT $M$ et al An integrated genome-wide approach to discover deregulated microRNAs in non-small cell lung cancer: Clinical significance of miR-23b-3p deregulation. Sci Rep 2015; 5: 13236. https://doi.org/10.1038/srep13236

[6] RECK M, POPAT S, REINMUTH N, DE RUYSSCHER $\mathrm{D}$, KERR KM et al. Metastatic non-small-cell lung cancer (NSCLC): ESMO Clinical Practice Guidelines for diagnosis, treatment and follow-up. Ann Oncol 2014; 25 Suppl 3: iii27-39. https://doi.org/10.1093/annonc/mdu199

[7] PAN J, XU Y, SONG H, ZHOU X, YAO Z et al. Extracts of Zuo Jin Wan, a traditional Chinese medicine, phenocopies 5-HTR1D antagonist in attenuating Wnt/beta-catenin signaling in colorectal cancer cells. BMC Complement Altern Med 2017; 17: 506. https://doi.org/10.1186/s12906-0172006-7

[8] WANG Q, WANG Q, WANG SF, JIAO LJ, ZHANG RX et al. Oral Chinese herbal medicine as maintenance treatment after chemotherapy for advanced non-small-cell lung cancer: a systematic review and meta-analysis. Curr Oncol 2017; 24: e269-e276. https://doi.org/10.3747/co.24.3561

[9] WANG S, WU X, TAN M, GONG J, TAN W et al. Fighting fire with fire: poisonous Chinese herbal medicine for cancer therapy. J Ethnopharmacol 2012; 140: 33-45. https://doi. org/10.1016/j.jep.2011.12.041

[10] PRADO S, FERREIRA GF, HARAZONO Y, SHIGA TM, RAZ A et al. Ripening-induced chemical modifications of papaya pectin inhibit cancer cell proliferation. Sci Rep 2017; 7: 16564. https://doi.org/10.1038/s41598-017-16709-3

[11] QIAN Y, HAN QH, LIU D, TU PF, ZENG KW et al. [Antitumor target identification and molecular mechanism study of total saponins from Albizia julibrissin]. Zhongguo Zhong Yao Za Zhi 2017; 42: 3661-3665. https://doi.org/10.19540/j. cnki.cjcmm.2017.0144

[12] WANG JN, ZHANG Y, SONG LY, PENG YB, LI WJ. [Chemical constituents from Pteris dispar and their antitumor activity in vitro]. Zhongguo Zhong Yao Za Zhi 2017; 42: 4159-4164. https://doi.org/10.19540/j.cnki.cjc$\mathrm{mm} .20170905 .002$ 
[13] TAN X, ZHOU X, CHEN HG. [Structure-activity relationship of plant polysaccharides]. Zhongguo Zhong Yao Za Zhi 2017; 42: 4104-4109. https://doi.org/10.19540/j.cnki. cjcmm.20170928.016

[14] HAN M, SUN P, LI Y, WU G, NIE J. Structural characterization of a polysaccharide from Sargassum henslowianum, and its immunomodulatory effect on gastric cancer rat. Int J Biol Macromol 2018; 108: 1120-1127. https://doi.org/10.1016/j. ijbiomac.2017.12.109

[15] KUMAR SSD, MAHESH A, ANTONIRAJ MG, RATHORE HS, HOURELD NN et al. Cellular imaging and folate receptor targeting delivery of gum kondagogu capped gold nanoparticles in cancer cells. Int J Biol Macromol 2018; 109: 220-230. https://doi.org/10.1016/j.ijbiomac.2017.12.069

[16] HAN Y, ZHANG A, SUN H, ZHANG Y, MENG X et al. High-throughput ultra high performance liquid chromatography combined with mass spectrometry approach for the rapid analysis and characterization of multiple constituents of the fruit of Acanthopanax senticosus (Rupr. et Maxim.) Harms. J Sep Sci 2017; 40: 2178-2187. https://doi. org/10.1002/jssc.201601445

[17] HAN J, LI JH, BAI G, SHEN GS1, CHEN J et al. Acanthopanax senticosus polysaccharides-induced intestinal tight junction injury alleviation via inhibition of NF-kappaB/ MLCK pathway in a mouse endotoxemia model. World J Gastroenterol 2017; 23: 2175-2184. https://doi.org/10.3748/ wjg.v23.i12.2175

[18] FEI XJ, ZHU LL, XIA LM, PENG WB, WANG Q. Acanthopanax senticosus attenuates inflammation in lipopolysaccharide-induced acute lung injury by inhibiting the NF-kappaB pathway. Genet Mol Res 2014; 13: 10537-10544. https://doi. org/10.4238/2014.December.12.16

[19] HAN J, LIU L, YU N, CHEN J, LIU B et al. Polysaccharides from Acanthopanax senticosus enhances intestinal integrity through inhibiting TLR4/NF-kappaB signaling pathways in lipopolysaccharide-challenged mice. Anim Sci J 2016; 87: 1011-1018. https://doi.org/10.1111/asj.12528

[20] WANG H, SUN B, ZHANG Z, CHEN J, HAO Q et al: Effects of Acanthopanax senticosus polysaccharide on the proliferation, apoptosis and cell cycle in human HepG2 cells. Pharmazie 2016; 71: 201-204. https://doi.org/10.1691/ ph.2016.5807

[21] XIE SS. [Immunoregulatory effect of polysaccharide of Acanthopanax senticosus (PAS). I. Immunological mechanism of PAS against cancer]. Zhonghua Zhong Liu Za Zhi 1989; 11: 338-340.

[22] BANG JS, CHUNG YH, CHUNG SJ, LEE HS, SONG EH et al. Clinical effect of a polysaccharide-rich extract of Acanthopanax senticosus on alcohol hangover. Pharmazie 2015; 70: 269-273. https://doi.org/10.1691/ph.2015.4786

[23] HUANG L, ZHAO H, HUANG B, ZHENG C, PENG W et al. Acanthopanax senticosus: review of botany, chemistry and pharmacology. Pharmazie 2011; 66: 83-97. https://doi. org/10.1691/ph.2011.0744

[24] HAHNFELDT P, PANIGRAHY D, FOLKMAN J, HLATKY L. Tumor development under angiogenic signaling: a dynamical theory of tumor growth, treatment response, and postvascular dormancy. Cancer Res 1999; 59: 4770-4775.
[25] TURASHVILI G, BROGI E. Tumor Heterogeneity in Breast Cancer. Front Med (Lausanne) 2017; 4: 227. https://doi. org/10.3389/fmed.2017.00227

[26] LOGAN CY, NUSSE R. The Wnt signaling pathway in development and disease. Annu Rev Cell Dev Biol 2004; 20: 781-810. https://doi.org/10.1146/annurev.cellbio.20.010403.113126

[27] FU Q, GAO Y, YANG F, MAO T, SUN Z et al. Suppression of microRNA-454 impedes the proliferation and invasion of prostate cancer cells by promoting N-myc downstreamregulated gene 2 and inhibiting WNT/beta-catenin signaling. Biomed Pharmacother 2018; 97: 120-127. https://doi. org/10.1016/j.biopha.2017.10.115

[28] HUANG J, HE Y, MCLEOD HL, XIE Y, XIAO D et al. miR302b inhibits tumorigenesis by targeting EphA2 via Wnt/ beta-catenin/EMT signaling cascade in gastric cancer. BMC Cancer 2017; 17: 886. https://doi.org/10.1186/s12885-0173875-3

[29] KRISHNAMURTHY N, KURZROCK R. Targeting the Wnt/beta-catenin pathway in cancer: Update on effectors and inhibitors. Cancer Treat Rev 2018; 62: 50-60. https://doi. org/10.1016/j.ctrv.2017.11.002

[30] LI X, LI M, CHEN J, DAI H, WANG L et al. SAMMSON drives the self-renewal of liver tumor initiating cells through EZH2-dependent Wnt/beta-catenin activation. Oncotarget 2017; 8: 103785-103796. https://doi.org/10.18632/oncotarget.21792

[31] WANG W, WEN Q, LUO J, CHU S, CHEN L et al. Suppression Of beta-catenin Nuclear Translocation By CGP57380 Decelerates Poor Progression And Potentiates Radiation-Induced Apoptosis in Nasopharyngeal Carcinoma. Theranostics 2017; 7: 2134-2149. https://doi.org/10.7150/thno.17665

[32] YANG J, HAN F, LIU W, CHEN H, HAO X et al. ALX4, an epigenetically down regulated tumor suppressor, inhibits breast cancer progression by interfering Wnt/beta-catenin pathway. J Exp Clin Cancer Res 2017; 36: 170. https://doi. org/10.1186/s13046-017-0643-9

[33] AYEKA PA, BIAN Y, GITHAIGA PM, ZHAO Y. The immunomodulatory activities of licorice polysaccharides (Glycyrrhiza uralensis Fisch.) in CT 26 tumor-bearing mice. BMC Complement Altern Med 2017; 17: 536. https://doi. org/10.1186/s12906-017-2030-7

[34] KU KH, PARK SJ, KIM JH, KWON HJ, CHANG HK et al. [Gastric Cancer Recurrence in 12 Years after Surgical Resection]. Korean J Gastroenterol 2017; 70: 296-300. https://doi. org/10.4166/kjg.2017.70.6.296

[35] LEE SG, KARADENIZ F, OH JH, YU GH, KONG CS. Inhibitory Effect of Hizikia fusiformis Solvent-Partitioned Fractions on Invasion and MMP Activity of HT1080 Human Fibrosarcoma Cells. Prev Nutr Food Sci 2017; 22: 184-190. https://doi.org/10.3746/pnf.2017.22.3.184

[36] LOPATINA KA, SAFONOVA EA, NEVSKAYA KV, STAKHEEVA MN, GUR'EV AM et al. Effect of Acorus calamus L. Polysaccharide on CD274 and CD326 Expression by Lewis Lung Carcinoma Cells in Mice. Bull Exp Biol Med 2017; 164: 102-105. https://doi.org/10.1007/s10517-0173934-4 
[37] SUN C, TAO Y, GAO Y, XIA Y, LIU Y et al. F-box protein 11 promotes the growth and metastasis of gastric cancer via PI3K/AKT pathway-mediated EMT. Biomed Pharmacother 2018; 98: 416-423. https://doi.org/10.1016/j.biopha.2017.12.088

[38] WU A, LI M, MAI Z, LI S, YANG Z. [CK2alpha Regulates the Metastases and Migration of Lung Adenocarcinoma A549 Cell Line through PI3K/Akt/GSK-3beta Signal Pathway]. Zhongguo Fei Ai Za Zhi 2017; 20: 233-238. https://doi. org/10.3779/j.issn.1009-3419.2017.04.11

[39] XU S, WANG T, GUAN ZR, ZHANG C, CHEN Y et al. FBXO2, a novel marker for metastasis in human gastric cancer. Biochem Biophys Res Commun 2018; 495: 2158-2164. https://doi.org/10.1016/j.bbrc.2017.12.097
[40] YAN J, ZHANG J, ZHANG X, LI X, LI L et al. SPARC is down-regulated by DNA methylation and functions as a tumor suppressor in T-cell lymphoma. Exp Cell Res 2018; 364: 125-132. https://doi.org/10.1016/j.yexcr.2017.12.022

[41] WU Y, TRAN T, DWABE S, SARKISSYAN M, KIM J et al. A83-01 inhibits TGF-beta-induced upregulation of Wnt3 and epithelial to mesenchymal transition in HER2-overexpressing breast cancer cells. Breast Cancer Res Treat 2017; 163: 449-460. https://doi.org/10.1007/s10549-017-4211-y

[42] CHOI SI, KIM SY, LEE JH, KIM JY, CHO EW et al. Osteopontin production by TM4SF4 signaling drives a positive feedback autocrine loop with the STAT3 pathway to maintain cancer stem cell-like properties in lung cancer cells. Oncotarget 2017; 8: 101284-101297. https://doi.org/10.18632/ oncotarget. 21021 